University of Nebraska - Lincoln

DigitalCommons@University of Nebraska - Lincoln

2004

\title{
Holocene loess deposition and soil formation as competing processes, Matanuska Valley, southern Alaska
}

Daniel R. Muhs

U.S. Geological Survey, dmuhs@usgs.gov

John P. McGeehin

U.S. Geological Survey

Jossh Beann

U.S. Geological Survey

Eric Fisher

U.S. Geological Survey

Follow this and additional works at: https://digitalcommons.unl.edu/usgsstaffpub

Part of the Earth Sciences Commons

Muhs, Daniel R.; McGeehin, John P.; Beann, Jossh; and Fisher, Eric, "Holocene loess deposition and soil formation as competing processes, Matanuska Valley, southern Alaska" (2004). USGS Staff -- Published Research. 177.

https://digitalcommons.unl.edu/usgsstaffpub/177

This Article is brought to you for free and open access by the US Geological Survey at DigitalCommons@University of Nebraska - Lincoln. It has been accepted for inclusion in USGS Staff -- Published Research by an authorized administrator of DigitalCommons@University of Nebraska - Lincoln. 


\title{
Holocene loess deposition and soil formation as competing processes, Matanuska Valley, southern Alaska
}

\author{
Daniel R. Muhs, ${ }^{\text {a,* }}$ John P. McGeehin, ${ }^{\mathrm{b}}$ Jossh Beann, ${ }^{\mathrm{a}}$ and Eric Fisher ${ }^{\mathrm{a}}$ \\ ${ }^{a}$ U.S. Geological Survey, MS 980, Box 25046, Federal Center, Denver, CO 80225, USA \\ ${ }^{\mathrm{b}}$ U.S. Geological Survey, MS 926A, National Center, Reston, VA 20192, USA
}

Received 21 August 2003

Available online 2 April 2004

\begin{abstract}
Although loess-paleosol sequences are among the most important records of Quaternary climate change and past dust deposition cycles, few modern examples of such sedimentation systems have been studied. Stratigraphic studies and 22 new accelerator mass spectrometry radiocarbon ages from the Matanuska Valley in southern Alaska show that loess deposition there began sometime after $\sim 6500{ }^{14} \mathrm{C}$ yr B.P. and has continued to the present. The silts are produced through grinding by the Matanuska and Knik glaciers, deposited as outwash, entrained by strong winds, and redeposited as loess. Over a downwind distance of $\sim 40 \mathrm{~km}$, loess thickness, sand content, and sand-pluscoarse-silt content decrease, whereas fine-silt content increases. Loess deposition was episodic, as shown by the presence of paleosols, at distances $>10 \mathrm{~km}$ from the outwash plain loess source. Stratigraphic complexity is at a maximum (i.e., the greatest number of loesses and paleosols) at intermediate $(10-25 \mathrm{~km})$ distances from the loess source. Surface soils increase in degree of development with distance downwind from the source, where sedimentation rates are lower. Proximal soils are Entisols or Inceptisols, whereas distal soils are Spodosols. Ratios of mobile $\mathrm{CaO}, \mathrm{K}_{2} \mathrm{O}$, and $\mathrm{Fe}_{2} \mathrm{O}_{3}$ to immobile $\mathrm{TiO}_{2}$ show decreases in surface horizons with distance from the source. Thus, as in China, where loess deposition also takes place today, eolian sedimentation and soil formation are competing processes. Study of loess and paleosols in southern Alaska shows that particle size can vary over short distances, loess deposition can be episodic over limited time intervals, and soils developed in stabilized loess can show considerable variability under the same vegetation.
\end{abstract}

(C) 2004 University of Washington. All rights reserved.

Keywords: Loess; Holocene; Matanuska Valley, Alaska; Paleosols; Radiocarbon dating; Inceptisols; Spodosols; Chemical weathering

\section{Introduction}

Loess (eolian silt) may cover as much as $10 \%$ of the Earth's surface and forms some of the world's most productive soils in midlatitude regions. In the humid midcontinent of North America, studies have shown that degree of development in both modern and buried loessderived soils increases as a function of distance downwind from a loess source (Ruhe, 1969a,b). Similar relations have been hypothesized for loess in semiarid and arid regions (Pye and Tsoar, 1987). The greater degree of soil development is attributed, in part, to differences in loess sedimentology, as finer grained (clay-rich) loess is deposited at distal localities. The rate of loess deposition may also be a factor, as soil development and weathering

\footnotetext{
* Corresponding author. Fax: (303) 236-5349.

E-mail address: dmuhs@usgs.gov (D.R. Muhs).
}

can proceed more effectively when loess sedimentation rates are lower. Hence, Verosub et al. (1993) described loess sedimentation and soil formation in China as competing processes. In the North American midcontinent, small amounts of dust probably were added to loessderived soils during the Holocene (e.g., Mason and Jacobs, 1998). Nevertheless, modern dust flux is low enough that it is incorporated into surface soils without stratigraphic expression in the field. Thus, testing hypotheses about loess sedimentation and soil formation as competing processes requires study in an area of active loess deposition.

Loess deposition took place in the Holocene at numerous localities in Alaska (Muhs et al., 2003a,b). However, in most parts of the region, loess deposition is not active at present or is occurring at a relatively low rate. One exception to this generalization is the Matanuska Valley of southern Alaska (Figs. 1a and 1b). Silt, derived from glacial meltwaters of the 

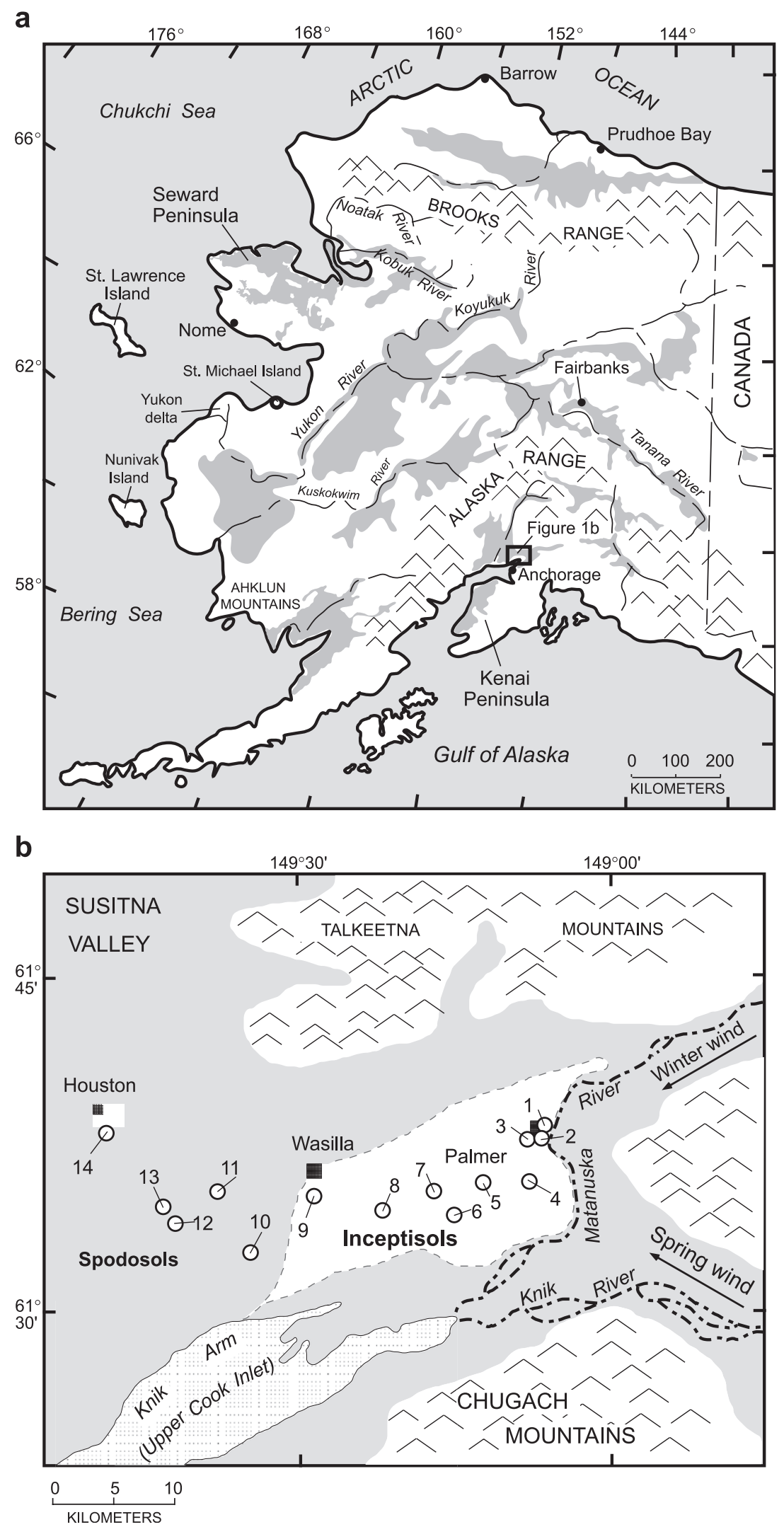

Fig. 1. (a) Map showing the distribution of loess deposits in Alaska, compiled from Hopkins (1963) and Sainsbury (1972) for the Seward Peninsula and Péwé (1975) for all other parts of the region. (b) Map of the Matanuska Valley region and surrounding mountain ranges and locations of loess profiles studied. See (a) for location of map area. 
Matanuska and Knik glaciers, is frequently entrained by the wind during most years (Tuck, 1938; Rieger and Juve, 1961; Trainer, 1961). Previous studies have shown that close to the Matanuska River, soils have a minimal degree of development compared to those farther downwind (Rieger and Juve, 1961; Trainer, 1961; Schoephorster, 1968; Clark and Kautz, 1998). Near-source soils are Entisols or Inceptisols with A/ $\mathrm{AC} / \mathrm{C}$ or $\mathrm{A} / \mathrm{E} / \mathrm{Bw} / \mathrm{C}$ profiles, whereas distal soils are Spodosols (or Inceptisols trending toward Spodosols) with $\mathrm{A} / \mathrm{E} /$ $\mathrm{Bw}[\mathrm{Bs}] / \mathrm{C}$ profiles. Previous investigators have hypothesized, but not proved, that paleosols exist in Matanuska Valley loess sections, suggesting that loess deposition has been episodic rather than continuous.

The present study was initiated to explore, in more detail than has been done previously, the relation between loess deposition and soil development in this area of active eolian sedimentation. Field studies were made of eolian sediment sections adjacent to the Matanuska River, near Palmer and in a transect west to Houston, $\sim 40 \mathrm{~km}$ downwind of the river (Fig. 1B). We hypothesized, based on the observations made by previous investigators, that loess thickness and particle size should show decreases to the west of the Matanuska River and that the degree of soil development and amount of chemical weathering should increase westward.

\section{Methods}

Loess sections were examined and described from river cut banks, road cuts, and hand-dug pits. Charcoal and plant macrofossils (mostly wood fragments) were collected for radiocarbon dating. Radiocarbon dating of charcoal and wood was done by accelerator mass spectrometry following extraction and graphitization procedures outlined by McGeehin et al. (2001). Soils and sediments were described and sampled by horizon for particle size analyses, bulk mineralogy, and geochemistry. Particle size distributions were determined by two methods: (1) using a traditional sieve and pipette method and (2) using a Malvern (trade name is for descriptive purposes only and does not imply endorsement by the U.S. Geological Survey) laser particle size analyzer. Both procedures were preceded by destruction of organic matter with hydrogen peroxide and dispersion with sodium hexametaphosphate. Similar to results reported by Mason et al. (2003), we found that the laser method gives results that differ from those of the sieve/pipette method. Because of the greater number of published analyses of loesses and soils using sieve and pipette, we report only results by that method here. Semiquantitative mineralogy of selected samples was determined by X-ray diffractometry on pulverized bulk sediment samples. Concentrations of selected major elements of bulk soils were determined by energy-dispersive X-ray fluorescence.

\section{Physical setting, climate, and vegetation}

The Matanuska Valley is a glacial-drift and loessmantled topographic and structural trough surrounded by the rugged Chugach Mountains to the south and the Talkeetna Mountains to the north (Fig. 1b). The mountains adjacent to the Matanuska Valley range as high as $1700-2100 \mathrm{~m}$ and are composed dominantly of crystalline (igneous and metamorphic) rocks of Mesozoic age, overlain by Tertiary sedimentary rocks (Barnes, 1962). Glacial deposits and fluvial deposits thus have clasts that reflect a highly varied source lithology. Tills in the Matanuska Valley are composed dominantly ( $\sim 50-$ $90 \%$ ) of metasedimentary or sedimentary rocks, with smaller $(\sim 20-40 \%)$ amounts of plutonic rocks and still smaller $(3-11 \%)$ amounts of volcanic rocks (Reger et al., 1996).

The Matanuska Valley was glaciated during stades of the last (Naptowne) glacial period (Reger and Updike, 1983; Reger et al., 1996). The valley is $15-40 \mathrm{~km}$ inside the outer limits of the youngest (Elmendorf) terminal moraine of the Naptowne glaciation, which was deposited between $\sim 13,700$ and $\sim 11,700{ }^{14} \mathrm{C}$ yr B.P. (Reger and Updike, 1983; Schmoll et al., 1999). Reger et al. (1996) report that the area was deglaciated no later than $9120 \pm$ $350{ }^{14} \mathrm{C}$ yr B.P., based on a radiocarbon age of peaty organic silt overlying Elmendorf-age outwash at a locality $\sim 13 \mathrm{~km}$ northwest of Palmer (Fig. 1B). However, the valley was likely deglaciated much earlier than this, because younger moraines of the Matanuska glacier, more than $60 \mathrm{~km}$ upvalley from Palmer, have a minimumlimiting age of $12,210 \pm 120{ }^{14} \mathrm{C}$ yr B.P. (Williams, 1986). Thus, the record of loess deposition and soil formation in the Matanuska Valley could be as old as $\sim 12,000{ }^{14}$ C yr B.P. $(\sim 14,000$ cal yr B.P. $)$.

The climate of the Matanuska Valley is intermediate between the maritime (cool and humid) environment of southern Alaska and the continental (cold and dry) environment of central Alaska. Mean annual precipitation at Palmer is $393 \mathrm{~mm}$, with an annual potential evapotranspiration of $466 \mathrm{~mm}$ (Muhs et al., 2001a; their Fig. 2). Maximum precipitation occurs during the summer months. Winter precipitation is dominated by snowstorms that result from major frontal systems developing from the Aleutian low pressure cell to the south. Mean July temperature at Palmer is $14.2^{\circ} \mathrm{C}$ and mean annual temperature is $1.9^{\circ} \mathrm{C}$. The Matanuska Valley is in the southernmost portion of Alaska's zone of discontinuous permafrost (Péwé, 1975). Based on 1953-1970 records at Anchorage International Airport (archived by the National Climatic Data Center, Asheville, NC, USA), the strongest July winds are from the south-southeast and south and average 3.9-5.7 m/s. April and October winds are also strongest from the south-southeast and average 4.5-5.2 m/s. In January, the strongest winds are from the north-northwest to north-northeast and average $3.3-4.0 \mathrm{~m} / \mathrm{s}$. In the Palmer 

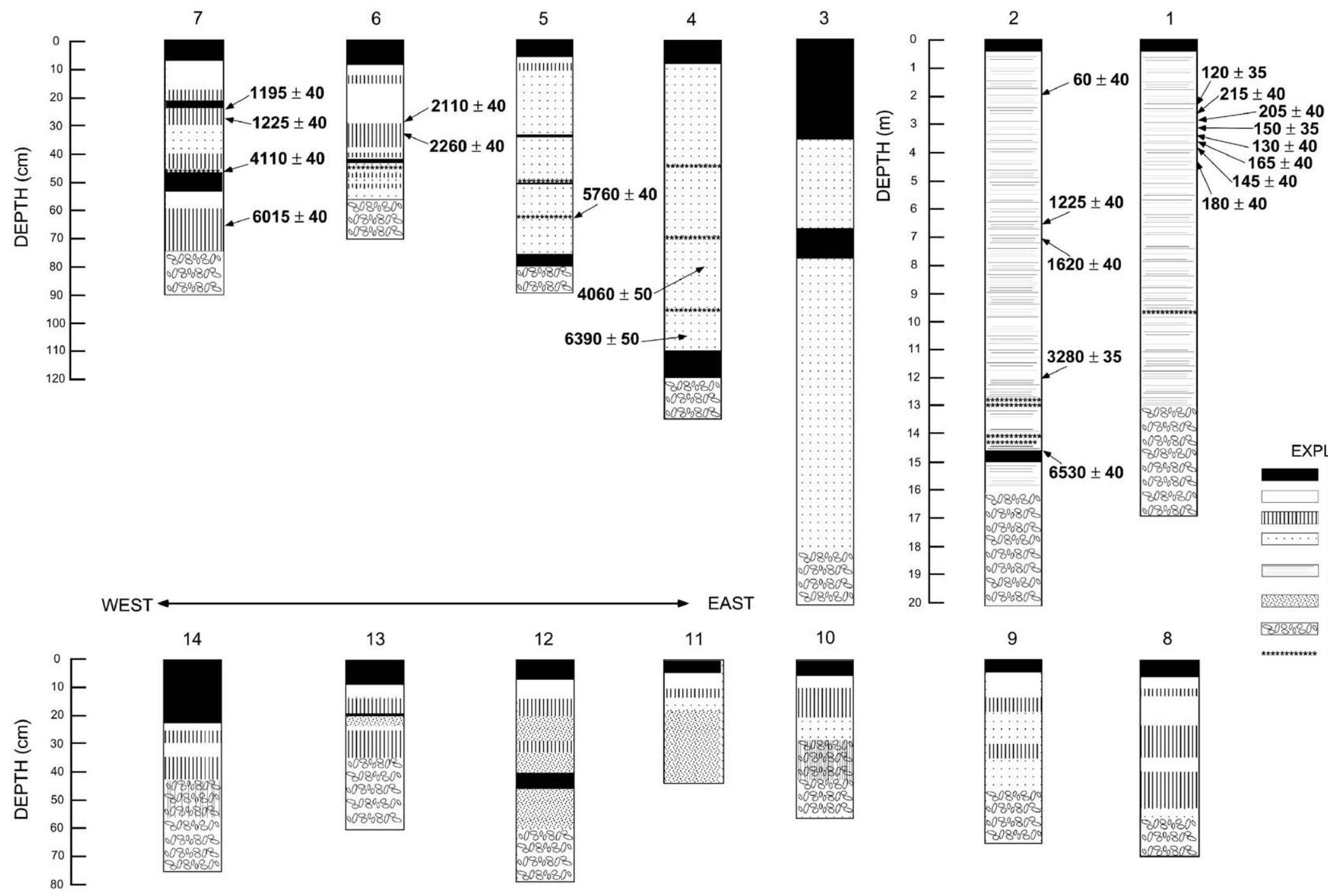

Fig. 2. Stratigraphy, soil horizons, and radiocarbon ages of loess profiles studied in the Matanuska Valley (see Fig. 1b for locations). All radiocarbon ages are uncalibrated; see Table 1 for calibrated ages. Note scale difference for Profiles 1 and 2. 
area, wind patterns are similar to those of Anchorage and are commonly strong enough to entrain silt during both winter and summer (Trainer, 1961).

Vegetation in the Matanuska Valley is predominantly boreal forest with some elements of coastal forest. Boreal forest trees include white spruce (Picea glauca), paper birch (Betula papyrifera), aspen (Populus tremuloides), and balsam poplar (Populus balsamifera). On poorly drained landscapes, white spruce is replaced by black spruce (Picea mariana). Coastal vegetation is represented by shrubs such as devil's club (Oplopanax horridum) and ferns (e.g., Dryopteris spp.). On south-facing slopes of the Talkeetna Mountains (Fig. 1B), treeline is at elevations of about 600-700 m; on north-facing slopes of the Chugach Mountains, treeline elevation is more variable, but is generally at elevations of 400-600 m. Above treeline, the vegetation is either shrub or alpine (herb) tundra. During the last (Naptowne) glacial period, vegetation in most of unglaciated Alaska, including the southern part of the region, was herb tundra (Ager and Brubaker, 1985). Pollen studies near Anchorage and Kenai indicate that boreal spruce reached the upper Cook Inlet area of southern Alaska at $\sim 8000{ }^{14}$ C yr B.P. (Ager, 1983; Ager and Brubaker, 1985). Vegetation in the Matanuska Valley itself has been spruce-dominated boreal forest for at least the past $\sim 2500$ yr (Forester et al., 1989).

\section{Stratigraphy and sedimentology of Matanuska Valley loess}

Examination of river cuts shows that eolian deposits are very thick close to the presumed sediment source. On the banks of the Matanuska River, eolian sediment is as much as $\sim 16 \mathrm{~m}$ thick and consists of horizontally interbedded silts and fine sands (Profiles 1 and 2 in Fig. 2). Of all the sediments examined in the region, those from Profiles 1 and 2 are the coarsest and mostly poorly sorted. Of those samples analyzed from these profiles, sand content ranges from 33 to $71 \%$ and silt content ranges from 17 to $58 \%$. These sediments have been described as having a dune-like morphology in this area (Reger and Updike, 1983) and thus resemble clifftop-type dune deposits. Near the base of Profile 2, two tephra doublets were observed, similar to those described by Trainer (1961), Riehle (1985), and Fontana (1988). Riehle (1985) showed that Hayes Volcano and other volcanoes in the region have erupted many times in the Holocene. Fontana (1988) used geochemical methods to show that many tephras in the Matanuska Valley are probably derived from eruptions of Hayes Volcano, $\sim 150 \mathrm{~km}$ due west of Palmer.

Eolian sediment thickness decreases rapidly with distance from the Matanuska River valley. Profiles 3, 4, and
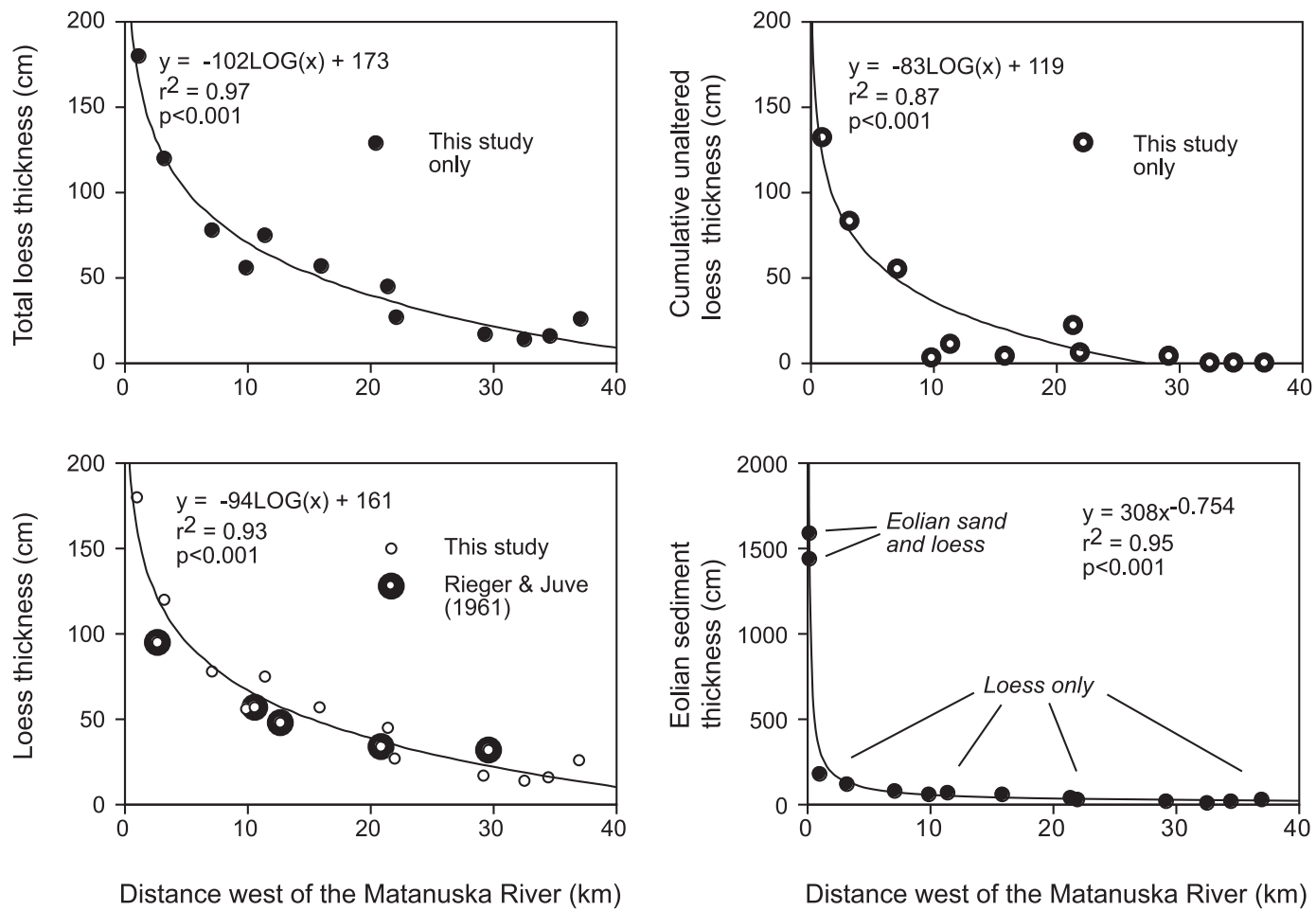

Fig. 3. Loess and eolian sediment profile thickness as a function of distance west of the Matanuska River. "Total loess thickness" refers to thickness of entire sediment column that has silt loam textures, including thicknesses of modern and buried soils. "Cumulative unaltered loess thickness" refers only to cumulative thickness of unaltered loess, i.e., those parts of the sediment column that do not contain soils. 
5, situated less than $8 \mathrm{~km}$ from the source, are less than $200 \mathrm{~cm}$ thick (Fig. 2). Eolian sediment in these profiles, and those farther downwind, are dominated by silt rather than silt and sand. Overall, both total eolian sediment thickness (i.e., including the cliff-top silts and sands) and loess thickness (including only the silt-dominated profiles) show systematic decreases with distance downwind from the Matanuska River (Fig. 3).

Sediment particle size data also show systematic changes downwind from the Matanuska River valley. Sand ( $>53 \mu \mathrm{m}$ fraction) and sand-plus-coarse-silt (53-20 $\mu \mathrm{m})$ contents show rapid decreases with distance, while fine-silt $(20-2 \mu \mathrm{m}$ fraction) content shows a systematic increase with distance (Fig. 4). The trends are similar to those that have been reported previously from the Matanuska Valley (Trainer, 1961) and are also similar to those from midcontinental North America for last-glacial-age loess, derived from major river systems such as the Illinois, Mississippi, and Missouri River valleys (Smith, 1942; Ruhe, 1969a,b; Muhs and Bettis, 2003). Similar trends have also been reported for China, as a function of
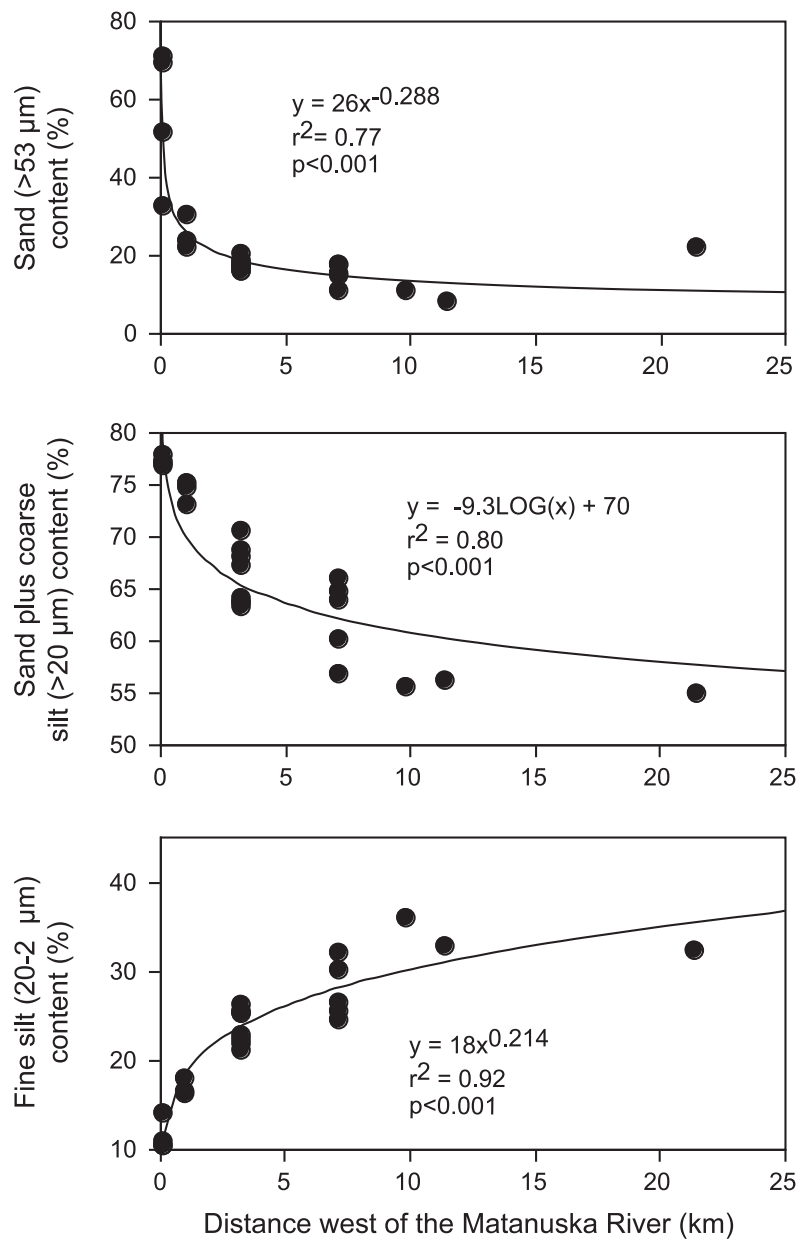

Fig. 4. Sand content, sand-plus-coarse-silt content and fine-silt content of unaltered loess shown as a function of distance west of the Matanuska River. distance downwind from desert basins (Porter, 2001). Distance-decay functions for particle size have traditionally been interpreted to reflect a winnowing of the coarse load away from a source.

Radiocarbon analyses show that eolian sediment deposition probably began about the same time, regardless of distance from the source (Fig. 2 and Table 1). Charcoal fragments from near the base of three sections, Profiles 2 (immediately adjacent to the Matanuska River), $4(3.2 \mathrm{~km}$ from the river), and $7(11.4 \mathrm{~km}$ from the river), yield similar ages, from $6530 \pm 40$ to $6015 \pm 40$ ${ }^{14} \mathrm{C}$ yr B.P. (about 7400 to $6800 \mathrm{cal}$ yr B.P.). These data suggest that after recession of the Matanuska glacier at the close of the Naptowne glaciation, around 12,210 \pm $120{ }^{14} \mathrm{C}$ yr B.P. (Williams, 1986), there was a period of little or no eolian sedimentation for several thousand years, an unexpected result that we discuss later.

At distances of $>10 \mathrm{~km}$ from the Matanuska River valley, loess deposition was episodic, as shown by the presence of paleosols (Fig. 2). Other investigators who have studied loess in the Matanuska Valley speculated that paleosols exist in these sections (Trainer, 1961; Rieger and Juve, 1961; Reger and Updike, 1983), and our studies confirm their presence. Paleosols in these loess sections are identified as buried $\mathrm{O}$ or $\mathrm{A}$ horizons (darker colors), E horizons (lighter colors), or B horizons (redder hues with high chromas). At increasingly greater distances west, the cumulative amount of unaltered loess in each profile decreases, ultimately to zero (Fig. 3). This observation indicates that farther from the loess source, pedogenesis has outcompeted loess accumulation.

\section{Chemical weathering in surface soils of Matanuska Valley loess}

Numerous minerals in Matanuska Valley loess can, under subaerial conditions, experience alteration. Optical examination of coarse silts by Davidson et al. (1959) and X-ray diffraction analysis of bulk samples in the present study indicate that the dominant minerals in unaltered Matanuska Valley loess are quartz, plagioclase, mica, chlorite (chamosite?), and hornblende. Davidson et al. (1959) also reported that rock fragments are abundant and K-feldspar is present in small amounts. Plagioclase, mica, chlorite, and hornblende are all minerals that undergo relatively rapid alteration under low $\mathrm{pH}$ conditions with sufficient rainfall (see review in Birkeland, 1999).

Previous studies of loess-derived soils in the Mississippi River valley have shown that certain major element ratios (mobile-to-immobile elements) provide useful proxies for mineral depletions (Jones and Beavers, 1966; Muhs et al., 2001b). We hypothesized that alteration of Matanuska Valley loess minerals should result in lower $\mathrm{CaO} / \mathrm{TiO}_{2}$ (plagioclase and hornblende loss) and $\mathrm{K}_{2} \mathrm{O} /$ 
Table 1

Profiles, depths, and radiocarbon ${ }^{\mathrm{a}}$ and calendar-year ages ${ }^{\mathrm{b}}$ of wood and charcoal from eolian sections, Matanuska Valley, Alaska

\begin{tabular}{|c|c|c|c|c|c|c|c|}
\hline Field No. & $\begin{array}{l}\text { USGS } \\
\text { radiocarbon } \\
\text { laboratory No. }\end{array}$ & $\begin{array}{l}\text { CAMS } \\
\text { laboratory No. }\end{array}$ & $\begin{array}{l}\text { Eolian } \\
\text { profile } \\
\text { No. }\end{array}$ & $\begin{array}{l}\text { Depth } \\
(\mathrm{cm})\end{array}$ & $\begin{array}{l}\text { Material } \\
\text { dated }\end{array}$ & $\begin{array}{l}\text { Radiocarbon age } \\
\left({ }^{14} \mathrm{C} \text { yr B.P. }\right)\end{array}$ & $\begin{array}{l}\text { Calibrated age } \\
(\text { cal yr B.P., } 2 \sigma)^{\mathrm{c}}\end{array}$ \\
\hline AK-2085 & WW-3842 & CAMS-85268 & 1 & 230 & Wood & $120 \pm 35$ & $280(97) 0^{*}$ \\
\hline AK-2086 & WW-3843 & CAMS-85269 & 1 & 265 & Wood & $215 \pm 40$ & $312(165) 2$ \\
\hline AK-2087 & WW-3844 & CAMS-85270 & 1 & 290 & Wood & $205 \pm 40$ & 309 (167) 1 \\
\hline AK-2088 & WW-3845 & CAMS-85271 & 1 & 310 & Wood & $150 \pm 35$ & 288 (144) $0 *$ \\
\hline AK-2089 & WW-3846 & CAMS-85272 & 1 & 340 & Wood & $130 \pm 40$ & 285 (140) $0 *$ \\
\hline AK-2090 & WW-3847 & CAMS-85273 & 1 & 360 & Wood & $165 \pm 40$ & 296 (190) $0 *$ \\
\hline AK-2091 & WW-3848 & CAMS-85274 & 1 & 380 & Wood & $145 \pm 40$ & 290 (143) $0 *$ \\
\hline AK-2092 & WW-3862 & CAMS-85699 & 1 & 430 & Wood & $180 \pm 40$ & 302 (150) $0 *$ \\
\hline AK-2101 & WW-3868 & CAMS-85705 & 2 & 190 & Wood & $60 \pm 40$ & $266\left(0^{*}\right) 0^{*}$ \\
\hline AK-2099 & WW-3865 & CAMS-85702 & 2 & 670 & Wood & $1225 \pm 40$ & 1264 (1171) 1015 \\
\hline AK-2100 & WW-3867 & CAMS-85704 & 2 & 700 & Wood & $1620 \pm 40$ & 1608 (1525) 1411 \\
\hline AK-2097 & WW-3863 & CAMS- 85700 & 2 & 1246 & Charcoal & $3280 \pm 35$ & 3630 (3473) 3404 \\
\hline AK-2098 & WW-3864 & CAMS-85701 & 2 & 1449 & Charcoal & $6530 \pm 40$ & 7555 (7428) 7333 \\
\hline AK-2019 & WW-3835 & CAMS-85261 & 4 & $80-82$ & Charcoal & $4060 \pm 50$ & 4810 (4564) 4416 \\
\hline AK-2022 & WW-3836 & CAMS-85262 & 4 & $100-110$ & Charcoal & $6390 \pm 50$ & 7424 (7294) 7214 \\
\hline AK-2033 & WW-3837 & CAMS-85263 & 5 & $60-66$ & Charcoal & $5760 \pm 40$ & 6716 (6548) 6413 \\
\hline AK-2128 & WW-3869 & CAMS-85706 & 6 & 29 & Charcoal & $2110 \pm 40$ & 2297 (2079) 1951 \\
\hline AK-2129A & WW-3870 & CAMS-85707 & 6 & $29-37$ & Charcoal & $2260 \pm 40$ & 2348 (2215) 2150 \\
\hline AK-2039 & WW-3838 & CAMS-85264 & 7 & 25 & Charcoal & $1195 \pm 40$ & 1258 (1121) 988 \\
\hline AK-2040 & WW-3839 & CAMS-85265 & 7 & $25-30$ & Charcoal & $1225 \pm 40$ & 1264 (1171) 1015 \\
\hline AK-2045 & WW-3840 & CAMS-85266 & 7 & $47-48$ & Charcoal & $4110 \pm 40$ & 4824 (4608) 4447 \\
\hline AK-2049 & WW-3841 & CAMS-85267 & 7 & $65-67$ & Charcoal & $6015 \pm 40$ & 6968 (6833) 6730 \\
\hline
\end{tabular}

${ }^{a}$ An assumed $\delta{ }^{13} \mathrm{C}$ value of -25 per mil was used for all samples.

${ }^{\mathrm{b}}$ Calendar-year calibrations made using program of Stuiver et al. (1998).

c " 0 *" represents a "negative" age B.P.

$\mathrm{TiO}_{2}$ (mica and $\mathrm{K}$-feldspar loss) values in surface horizons of soils that have experienced more chemical weathering, as in the Mississippi River valley. We further hypothesized that the greatest degree of chemical weathering should occur in the Spodosols (or soils trending toward Spodosols) that occur farther from the loess source, where sedimentation rates are lower and chemical weathering can outpace deposition.

Analyses of bulk samples indicate that a greater degree of chemical weathering is found in surface horizons of soils that are farther downwind (Fig. 5). We analyzed $\mathrm{O}$ horizons and $\mathrm{E}$ horizons (or uppermost $\mathrm{C}$ horizons where $\mathrm{E}$ horizons are absent) separately, but both show decreases in $\mathrm{CaO} / \mathrm{TiO}_{2}$ and $\mathrm{K}_{2} \mathrm{O} / \mathrm{TiO}_{2}$ values as a function of distance west of the Matanuska River valley. It is interesting to note that $\mathrm{CaO} / \mathrm{TiO}_{2}$ and $\mathrm{K}_{2} \mathrm{O} /$ $\mathrm{TiO}_{2}$ values are higher, in general, in $\mathrm{O}$ horizons than in the corresponding $\mathrm{E}$ horizons, particularly for $\mathrm{CaO} / \mathrm{TiO}_{2}$ values. We hypothesize that this trend may be due to biocycling that periodically enriches the $\mathrm{O}$ horizons. Plant litter that is deposited on the soil surface may return some nutrients, such as $\mathrm{Ca}$ and $\mathrm{K}$, to the $\mathrm{O}$ horizon that offset some loss of soluble elements by chemical weathering. Muhs et al. (2001a) reported that modern loessderived soils under boreal forest near Fairbanks, Alaska, also showed enrichments in $\mathrm{CaO} / \mathrm{TiO}_{2}$ and $\mathrm{K}_{2} \mathrm{O} / \mathrm{TiO}_{2}$ values in surface $\mathrm{O}$ horizons compared to $\mathrm{E}$ horizons. Alternatively, this trend could reflect deposition of unal- tered, very recent loess in the $\mathrm{O}$ horizons. In any case, the trends show that surface horizons of distal Spodosols have experienced more chemical weathering than the surface horizons of proximal Entisols/Inceptisols.

Spodosols are characterized by well-expressed O or A; $\mathrm{E}$; and $\mathrm{Bs}, \mathrm{Bh}$, or Bsh horizons. This kind of profile sequence results from a suite of pedogenic processes collectively called podzolization. Among these processes are translocation of organic matter, $\mathrm{Al}$, and $\mathrm{Fe}$ out of the $\mathrm{O}, \mathrm{A}$, and $\mathrm{E}$ horizons and accumulation within the $\mathrm{B}$ horizon. The low soil $\mathrm{pH}$ values that develop in surface $(\mathrm{O}, \mathrm{A}$, and $\mathrm{E})$ horizons from boreal forest vegetation plus the presence of chelates allow $\mathrm{Al}$ and $\mathrm{Fe}$ to go into solution and migrate into the $\mathrm{B}$ horizon. The best measure of the abundance of iron oxides that migrate out of $\mathrm{E}$ horizons and accumulate in $\mathrm{B}$ horizons is dithionite-extractable $\mathrm{Fe}$ (Birkeland, 1999, p. 91), but total $\mathrm{Fe}_{2} \mathrm{O}_{3}$ also shows increases in $\mathrm{B}$ horizons relative to overlying $\mathrm{E}$ horizons or underlying $\mathrm{C}$ horizons in Spodosols (Aide and Pavich, 2002). Results from the present study show that $\mathrm{E}$ horizons of surface soils have systematically lower total $\mathrm{Fe}_{2} \mathrm{O}_{3}$ contents as a function of distance from the Matanuska River (Fig. 6). In fact, the amount of total $\mathrm{Fe}_{2} \mathrm{O}_{3}$ in the $\mathrm{E}$ horizon decreases by a factor of 2 from the near-source Entisols/Inceptisols to the distal Spodosols. The $\mathrm{B}$ horizons of the surface soils do not show a complementary increase in $\mathrm{Fe}_{2} \mathrm{O}_{3}$ content with distance from the source, but the ratio of total $\mathrm{Fe}_{2} \mathrm{O}_{3}$ in the $\mathrm{B}$ 

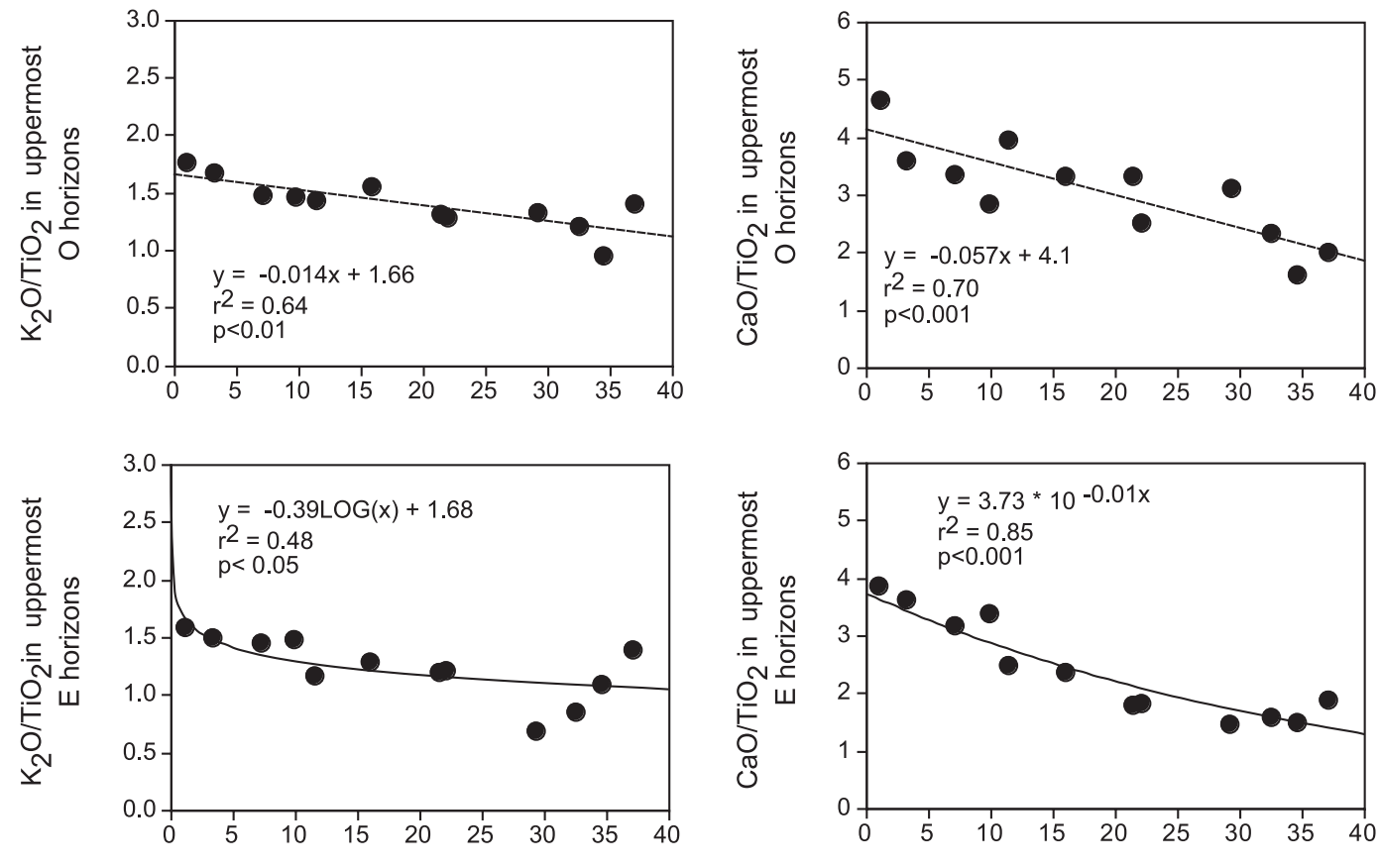

Distance west of the Matanuska River $(\mathrm{km})$

Distance west of the Matanuska River $(\mathrm{km})$

Fig. 5. Ratios of mobile to immobile elements in $\mathrm{O}$ and $\mathrm{E}$ horizons of uppermost soils shown as a function of distance west of the Matanuska River.

horizon to total $\mathrm{Fe}_{2} \mathrm{O}_{3}$ in the $\mathrm{E}$ horizon shows a systematic increase to the west (Fig. 6). We also plotted the maximum total $\mathrm{Fe}_{2} \mathrm{O}_{3}$ content of any $\mathrm{B}$ horizon (whether in the surface soil or in a buried soil) as a function of distance from the Matanuska River and this property shows a significant increase to the west (Fig. 6). These observations support those of earlier workers (Rieger and Juve, 1961; Trainer, 1961; Schoephorster, 1968; Clark and Kautz, 1998) that the degree of podzolization in the Matanuska Valley increases to the west.
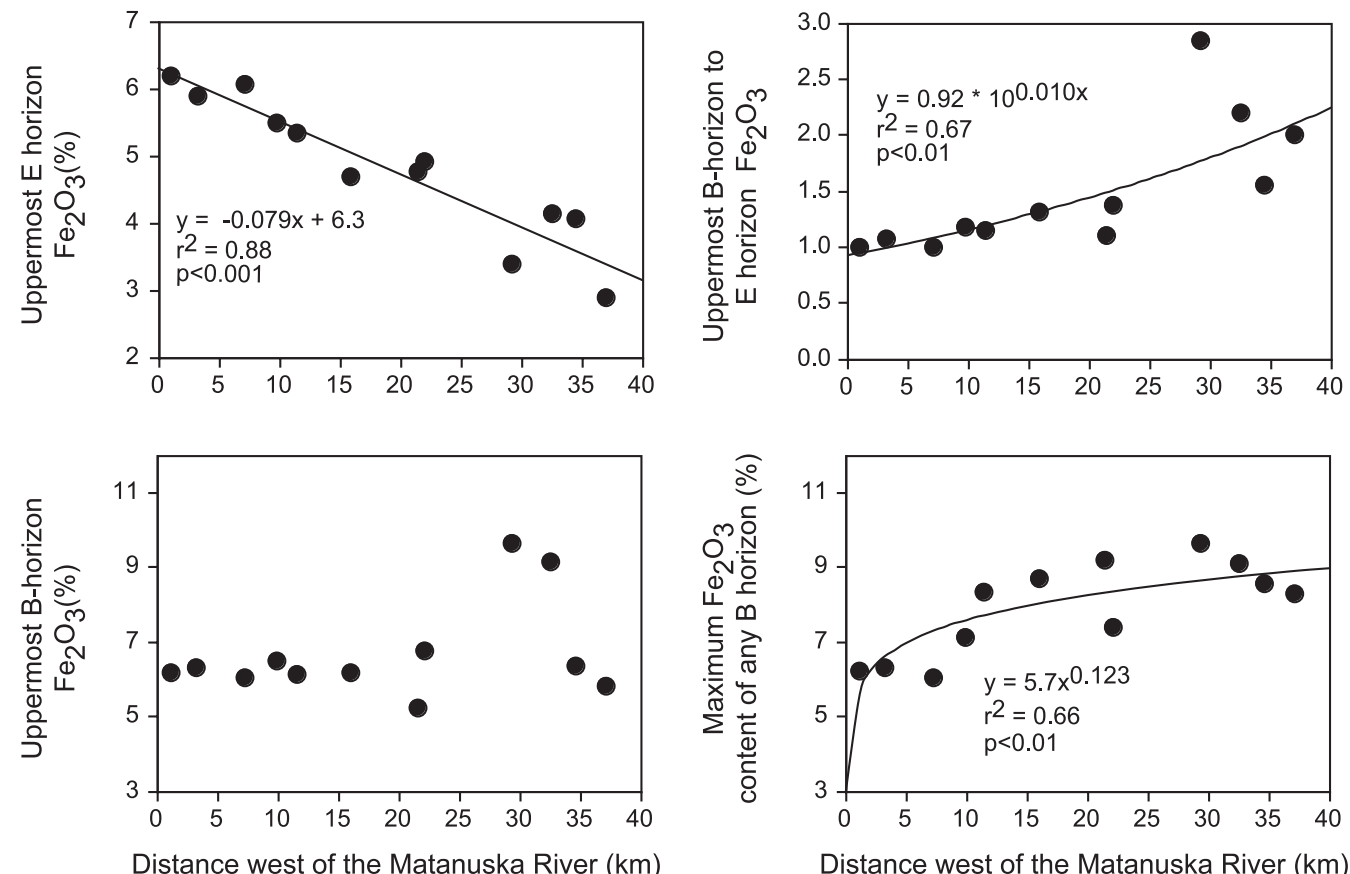

Fig. 6. Total Fe content $\left(\right.$ as $\left.\mathrm{Fe}_{2} \mathrm{O}_{3}\right)$ in $\mathrm{E}$ and $\mathrm{B}$ horizons of uppermost soils and buried soils shown as a function of distance west of the Matanuska River. 


\section{Discussion}

Radiocarbon dating suggests that eolian sediment accumulation began sometime after $\sim 6500{ }^{14} \mathrm{C}$ yr B.P. ( $\sim 7400$ cal yr B.P.). It is not clear why there is little or no record of loess sedimentation in the Matanuska Valley prior to the mid-Holocene. One possibility is that sediment supplies from glacial sources were limited. Schmoll et al. (1999) have summarized the Holocene glacial history of the Anchorage area, particularly that of the adjacent Chugach Mountains, which contain the Matanuska and Knik glaciers. They recognize three broad age groups of Holocene moraines, Winner Creek, Deadman, and Tunnel, from oldest to youngest. Winner Creek moraines could be $\sim 8000{ }^{14} \mathrm{C}$ yr B.P., Deadman moraines could be $\sim 3500{ }^{14} \mathrm{C}$ yr B.P., and Tunnel moraines apparently date to the Little Ice Age of the past few hundred years. Schmoll et al. (1999) have mapped and correlated moraines of these three age groups in the Knik valley. Thus, it is possible that loess sedimentation did not begin until sometime after recession of the glaciers that built the Winner Creek moraines, if they are $\sim 8000$ ${ }^{14} \mathrm{C}$ yr B.P. Studies in central Alaska suggest that preservation of a loess record may also require the presence of boreal forest, which serves as an efficient dust trap compared to herb tundra or even shrub tundra (Muhs et al., 2003b). Nevertheless, pollen data indicate that spruce-dominated boreal forest probably reached southern Alaska, including the Matanuska Valley region, by $\sim 8000{ }^{14} \mathrm{C}$ yr B.P. (Ager, 1983; Ager and Brubaker, 1985), well before the earliest records of loess sedimentation. Another possibility for the lack of an early Holocene loess record is that winds were of lower competence during this period. Too few data currently exist to determine whether the lack of a loess record in the early to mid-Holocene is due to supply limitations, transport limitations, or both.

The stratigraphy and radiocarbon chronology presented here indicate that although loess accumulation in the Matanuska Valley did not begin until the mid-Holocene, it has been episodic since that time. Although basal radiocarbon ages indicate similar beginning times for loess accumulation in widely separated sections, stratigraphic records are remarkably different over even short distances. For example, during the period from about 6000 to $4000{ }^{14} \mathrm{C}$ yr B.P., Profile 2 (immediately adjacent to the source) and Profile $4, \sim 3 \mathrm{~km}$ from the source, were experiencing loess or eolian sand sedimentation with no intervals of pedogenesis. In contrast, Profile 7, just $8 \mathrm{~km}$ west of Profile 4, was experiencing pedogenesis during the same period and developed a morphologically well-expressed soil with an $\mathrm{A} / \mathrm{E} / \mathrm{Bw} 1 / \mathrm{Bw} 2$ horizon sequence (Fig. 2).

Stratigraphic data also indicate that the complexity of loess sedimentation and pedogenic cycles is at a maximum at intermediate distances from the loess source. At localities near the source (Profiles 1, 2, 3, 4, and 5), the sections show minimal degrees of surface soil development and at most only a single buried soil. At distal localities (e.g., Profiles 10, 11, 13, and 14) surface soils are well developed but also show at most only one buried soil. In contrast, at intermediate localities (Profiles 6, 7, and 8) there are fairly well-developed surface soils and two to four buried soils.

Sedimentologic data from the youngest loess units in the Matanuska Valley show that textures change rapidly with distance from the source. Fine-silt contents increase by more than a factor of 3 within $15 \mathrm{~km}$ of transport (Fig. 4). These rates of change are much greater than those reported for loess of the last glacial age in midcontinental North America (Ruhe, 1969a,b; Muhs and Bettis, 2003). The difference between rates of change in the two regions suggests that the winds which transport loess in southern Alaska may be much more localized than those which transported loess in midcontinental North America during the last glacial period. In addition, the geomorphology of the source valley may be important. The Matanuska and Knik River valleys are much narrower than the Mississippi and Missouri River valleys of the North American midcontinent. This may result in a much more pronounced flow separation at the upland margins of the Alaskan valleys, with deposition of a larger proportion of the coarse load than is the case in the midcontinent.

Stratigraphic and pedologic data show that soils develop rapidly in the Matanuska Valley at relatively short distances from the loess source. Morphologically wellexpressed Spodosols (or soils trending toward Spodosols) have developed at distances of $\sim 16 \mathrm{~km}$ and greater from the Matanuska River. Geochemical data indicate that mobile elements such as $\mathrm{Ca}, \mathrm{K}$, and $\mathrm{Fe}$ show systematic decreases in surface horizons with distance from the loess source. Such trends probably reflect increasing amounts of pedogenesis and chemical weathering in distal localities where loess sedimentation rates are lower.

Systematic increases in chemical weathering and Spodosol formation over a Holocene time scale are actually unexpected results for the Matanuska Valley. In southeastern Alaska, near Mendenhall Glacier, soils with $\mathrm{O} / \mathrm{E} /$ $\mathrm{Bs} / \mathrm{C}$ profiles can form in less than $100 \mathrm{yr}$ and fully developed Spodosols can form in less than $300 \mathrm{yr}$ (Alexander and Burt, 1996). Southeastern Alaska receives $>2500 \mathrm{~mm} / \mathrm{yr}$ of precipitation and has a net moisture surplus in every month of the year. In contrast, Palmer receives less than $400 \mathrm{~mm} / \mathrm{yr}$ of precipitation and has an annual moisture deficit, based on calculations of potential evapotranspiration (Muhs et al., 2001a). Thus, with a net moisture deficit, it is surprising that Spodosols form relatively quickly and changes in degree of chemical weathering are so systematic. One possible explanation for this is that Spodosol-forming processes occur episodically, during seasons in which precipitation exceeds 
evapotranspiration. Another possibility is that with a forest cover and moss-rich ground cover, evapotranspiration is actually lower than precipitation, a microclimatic effect that is not taken into account with the potential evapotranspiration calculations of Muhs et al. (2001a).

Secondary factors may also enhance moisture retention and chemical weathering distant from the loess source. Ping (1987) and Clark and Kautz (1998) point out that in areas close to the Matanuska River, wind strengths are high and winter snow is removed by wind. Wind removal of snow decreases dramatically within very short distances west of the Matanuska River, however, and snowpack remains all winter long at distal localities. Schaetzl and Isard (1996), studying the degree of Spodosol development in Wisconsin and Michigan, showed that the best developed Spodosols occur in areas that have the thickest and longest lasting winter snowpacks. Thick snowpacks have dual effects on the underlying soil: it is insulated, such that winter ground temperatures are higher than they would be otherwise, and moisture content remains higher, particularly during the spring snowmelt season. Higher temperatures and a greater flux of meltwater would both act to enhance the leaching of soluble elements and amplify the podzolization, or Spodosol-forming processes. We suggest that the greater degree of soil development and greater amount of chemical weathering at distal localities in the Matanuska Valley are a function not only of the longer periods available for pedogenesis (because of the lower sedimentation rate), but also of greater moisture flux due to thicker and longer lasting winter snowpacks (Fig. 7).

Our studies have implications for interpretations of loess and soil records elsewhere in North America and Europe. Pollen and macrofossil data, combined with radiocarbon ages, from Illinois, Iowa, Nebraska, and Kansas indicate that a spruce-dominated boreal forest or spruce parkland was present on the loess-mantled landscape south of the Laurentide ice sheet during the last glacial period (Ruhe, 1969b; Baker et al., 1986, 1989; Wells and Stewart, 1987; Muhs et al., 2001b). Thus, the midcontinent region of North America during last glacial time could have had a landscape that resembled, in some respects, the present boreal forest and loess-covered landscape of the present Matanuska Valley. If so, then the results presented here suggest that some of the chemical weathering and soil development found in loess-derived soils of the midcontinent might have taken place during the main period of loess fall, at least at distal localities. However, midcontinent loesses were originally calcareous, whereas Matanuska Valley loess has few or no carbonates. Thus, weathering of noncarbonate minerals can take place more rapidly in Alaska than it did in the midcontinent. Nevertheless, our results imply that some of the chemical weathering in midcontinent loess-derived soils may have taken place under a past boreal forest, rather than under later Holocene deciduous forest or prairie.

Finally, the Alaskan results show that loess deposition in a region need not be continuous, even over time scales
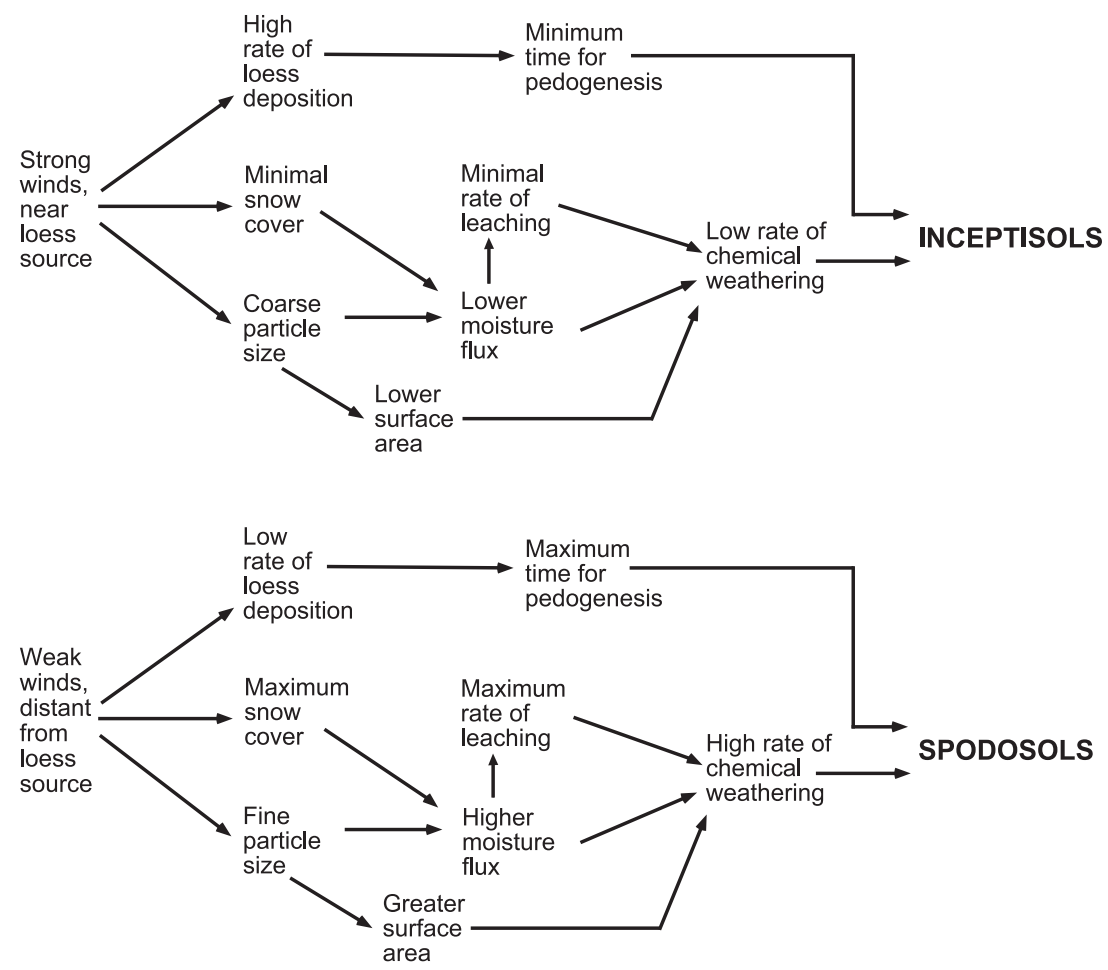

Fig. 7. Model showing different processes (near source and distant from source) as dominant controls on degree of soil development in the Matanuska Valley. 
shorter than interglacial-glacial cycles. Last glacial loess deposition in midcontinental North America and Europe also may not have been continuous. Several investigators have reported buried soils within last glacial loess in midcontinental North America (Ruhe et al., 1971; Hayward and Lowell, 1993; Wang et al., 2000) and Europe (Rousseau et al., 2002). Verosub et al. (1993) described loess accumulation and soil formation as competing processes in China. We suggest that this is also an appropriate description for southern Alaska at present and may have also been the case for midcontinental North America and Europe during the last glacial period.

\section{Summary}

Studies in the Matanuska Valley of Alaska show that loess deposition was episodic, based on the presence of paleosols, and the number of paleosols is at a maximum at intermediate distances from the loess source. Loess thickness and particle size show systematic decreases downwind from the presumed loess sources. On the other hand, the degree of development of surface soils and amount of chemical weathering in surface horizons increase downwind, due both to lower rates of sedimentation and to greater moisture flux. Results from the Matanuska Valley show that loess deposition rates, stratigraphy, particle size, and degree of surface soil development can vary over very short distances. As in China, loess deposition and soil formation in southern Alaska are competing processes. These findings have important implications for interpretations of loess records in midcontinental North America and Europe.

\section{Acknowledgments}

This study was supported by the Earth Surface Dynamics Program of the U.S. Geological Survey and is a contribution to the Eolian History of North America Project. Alison Till (USGS, Anchorage, AK) provided essential logistical support, which we appreciate. Gary Skipp (USGS, Denver, CO) provided the mineralogical data and Art Bettis (University of Iowa, Iowa City) provided the particle size data by sieve/pipette. Tom Ager (USGS, Denver), Art Bettis (University of Iowa), Rolfe Mandel (Kansas Geological Survey, KS), and Jim Begét (University of Alaska, Anchorage) read an earlier version of the paper and provided helpful comments for its improvement.

\section{References}

Ager, T.A., 1983. Holocene vegetational history of Alaska. In: Wright, H.E. (Ed.), Late Quaternary Environments of the United States, vol. 2. The Holocene. Univ. of Minnesota Press, Minneapolis, pp. 128-141.
Ager, T.A., Brubaker, L., 1985. Quaternary palynology and vegetational history of Alaska. In: Bryant Jr., V.M., Holloway, R.G. (Eds.), Pollen Records of Late-Quaternary North American Sediments. American Association of Stratigraphic Palynologists Foundation, Dallas, TX, pp. $353-383$.

Aide, M.T., Pavich, Z., 2002. Rare earth element mobilization and migration in a Wisconsin Spodosol. Soil Science 167, 680-691.

Alexander, E.B., Burt, R., 1996. Soil development on moraines of Mendenhall Glacier, southeast Alaska: 1. The moraines and soil morphology. Geoderma 72, 1-17.

Baker, R.G., Rhodes, R.S., Schwert, D.P., Ashworth, A.C., Frest, T.J., Hallberg, G.R., Janssens, J.A., 1986. A full-glacial biota from southeastern Iowa, USA. Journal of Quaternary Science 1, 91-107.

Baker, R.G., Sullivan, A.E., Hallberg, G.R., Horton, D.G., 1989. Vegetational changes in western Illinois during the onset of late Wisconsinan glaciation. Ecology 70, 1363-1376.

Barnes, F.F., 1962. Geologic map of Lower Matanuska Valley, Alaska. U.S. Geological Survey Miscellaneous Investigations Map I-0359, scale $1: 63,360$.

Birkeland, P.W., 1999. Soils and Geomorphology. Oxford Univ. Press, New York.

Clark, M.H., Kautz, D.R., 1998. Soil Survey of Matanuska-Susitna Valley Area, Alaska U.S. Natural Resources Conservation Service, U.S. Government Printing Office, Washington, DC.

Davidson, D.T., Roy, C.J., et al., 1959. The geology and engineering characteristics of some Alaskan soils. Iowa State Univ. Bull. 186, $1-99$.

Fontana, M.R., 1988. Holocene tephrochronology of the Matanuska Valley, Alaska. Unpublished M.S. thesis, Univ. of Alaska, Fairbanks.

Forester, R.M., Delorme, L.D., Ager, T.A., 1989. A lacustrine record of late Holocene climate change from south-central Alaska. American Geophysical Union, Geophysical Monogr. 55, 33-40.

Hayward, R.K., Lowell, T.V., 1993. Variations in loess accumulation rates in the mid-continent, United States, as reflected by magnetic susceptibility. Geology 21, 821-824.

Hopkins, D.M., 1963. Geology of the Imuruk Lake area, Seward Peninsula, Alaska. U.S. Geological Survey Bull., 1141-C.

Jones, R.L., Beavers, A.H., 1966. Weathering in surface horizons of Illinois soils. Soil Science Society of America Proceedings 30, 621-624.

Mason, J.A., Jacobs, P.M., 1998. Chemical and particle size evidence for addition of fine dust to soils of the midwestern United States. Geology 26, $1135-1138$.

Mason, J.A., Jacobs, P.M., Greene, R.S.B., Nettleton, W.D., 2003. Sedimentary aggregates in the Peoria Loess of Nebraska, USA. Catena 53, $377-397$.

McGeehin, J., Burr, G.S., Jull, A.J.T., Reines, D., Gosse, J., Davis, P.T., Muhs, D., Southon, J.R., 2001. Stepped-combustion ${ }^{14} \mathrm{C}$ dating of sediment: a comparison with established techniques. Radiocarbon 43, $255-261$.

Muhs, D.R., Ager, T.A., Been, J., Bradbury, J.P., Dean, W.E., 2003a. A late Quaternary record of eolian silt deposition in a maar lake, St. Michael Island, western Alaska. Quaternary Research 60, 110-122.

Muhs, D.R., Ager, T.A., Begét, J.B., 2001a. Vegetation and paleoclimate of the last interglacial period, central Alaska. Quaternary Science Reviews 20, $41-61$.

Muhs, D.R., Ager, T.A., Bettis III, E.A., McGeehin, J., Been, J.M., Begét, J.E., Pavich, M.J., Stafford Jr., T.W., Stevens, D.S.P., 2003b. Stratigraphy and paleoclimatic significance of late Quaternary loess-paleosol sequences of the Last Interglacial-Glacial cycle in central Alaska. Quaternary Science Reviews 22, 1947-1986.

Muhs, D.R., Bettis III, E.A., 2003. Quaternary loess-paleosol sequences as examples of climate-driven sedimentary extremes. In: Chan, M.A., Archer, A.W. (Eds.), Extreme Depositional Environments: Mega End Members in Geologic Time. Geological Society of America Special Paper, vol. 370, Geological Society of America, Boulder, Colorado, pp. 53-74.

Muhs, D.R., Bettis III, E.A., Been, J., McGeehin, J., 2001b. Impact of climate and parent material on chemical weathering in loess-derived 
soils of the Mississippi River Valley. Soil Science Society of America Journal 65, 1761-1777.

Péwé, T.L., 1975. Quaternary Geology of Alaska. U.S. Geological Survey Professional Paper, 835.

Ping, C.L., 1987. Soil temperature profiles of two Alaskan soils. Soil Science Society of America Journal 51, 1010-1018.

Porter, S.C., 2001. Chinese loess record of monsoon climate during the last glacial-interglacial cycle. Earth-Science Reviews 54, 115-128.

Pye, K., Tsoar, H., 1987. The mechanics and geological implications of dust transport and deposition in deserts with particular reference to loess formation and sand dune diagenesis in the northern Negev, Israel. In: Frostick, L., Reid, I. (Eds.), Desert Sediments: Ancient and ModernGeological Society Special Publication, vol. 35, Unwin Hyman, London, pp. 139-156.

Reger, R.D., Pinney, D.S., Burke, R.M., Wiltse, M.A., 1996. Catalog and initial analyses of geologic data related to middle to late Quaternary deposits, Cook Inlet region, Alaska. State of Alaska Division of Geological and Geophysical Surveys Report of Investigations 95-6, 1-188.

Reger, R.D., Updike, R.G., 1983. Upper Cook Inlet region and the Matanuska Valley. In: Péwé, T.L., Reger, R.D. (Eds.), Guidebook to Permafrost and Quaternary Geology along the Richardson and Glenn Highways between Fairbanks and Anchorage, Alaska. State of Alaska Division of Geological and Geophysical Surveys, Guidebook, vol. 1, Alaska Division of Geological and Geophysical Surveys, Fairbanks, Alaska, pp. 185-259.

Rieger, S., Juve, R.L., 1961. Soil development in recent loess in the Matanuska Valley, Alaska. Soil Science Society of America Proceedings 25, $243-248$.

Riehle, J.R., 1985. A reconnaissance of the major Holocene tephra deposits in the upper Cook Inlet region, Alaska. Journal of Volcanology and Geothermal Research 26, 37-74.

Rousseau, D.D., Antoine, P., Hatté, C., Lang, A., Zöller, L., Fontugne, M., Ben Othman, D., Luck, J.M., Moine, O., Labonne, M., Bentaleb, I., Jolly, D., 2002. Abrupt millennial climatic changes from Nussloch (Germany) Upper Weichselian eolian records during the Last Glaciation. Quaternary Science Reviews 21, 1577-1582.

Ruhe, R.V., 1969a. Application of pedology to Quaternary research. In: Pawluk, S. (Ed.), Pedology and Quaternary Research. National Research Council of Canada and University of Alberta, Edmonton, pp. 1-23.

Ruhe, R.V., 1969b. Quaternary Landscapes in Iowa. Iowa State University Press, Ames.
Ruhe, R.V., Miller, G.A., Vreeken, W.J., 1971. Paleosols, loess sedimentation and soil stratigraphy. In: Yaalon, D.H. (Ed.), PaleopedologyOrigin, Nature and Dating of Paleosols. Israel Universities Press, Jerusalem, pp. 41-59.

Sainsbury, C.L., 1972. Geologic Map of the Teller Quadrangle, Western Seward Peninsula, Alaska. U.S. Geological Survey Miscellaneous Geologic Investigations Map I-685, scale 1:250,000.

Schaetzl, R.J., Isard, S.A., 1996. Regional-scale relationships between climate and strength of podzolization in the Great Lakes region, North America. Catena 28, 47-69.

Schoephorster, D.B., 1968. Soil Survey of Matanuska Valley Area, Alaska U.S. Soil Conservation Service, U.S. Government Printing Office, Washington, DC.

Schmoll, H.R., Yehle, L.A., Updike, R.G., 1999. Summary of Quaternary geology of the Municipality of Anchorage, Alaska. Quaternary International $60,3-36$.

Smith, G.D., 1942. Illinois loess: variations in its properties and distribution, a pedologic interpretation. University of Illinois Agricultural Experiment Station Bull. 490, 139-184.

Stuiver, M., Reimer, P.J., Bard, E., Beck, J.W., Burr, G.S., Hughen, K.A., Kromer, B., McCormac, G., van der Plicht, J., Spurk, M., 1998. INTCAL 98 radiocarbon age calibration, 24,000-0 cal B.P. Radiocarbon $40,1041-1083$.

Trainer, F.W., 1961. Eolian deposits of the Matanuska Valley agricultural area, Alaska. U.S. Geological Survey Bull., 1121-C.

Tuck, R., 1938. The loess of the Matanuska Valley, Alaska. Journal of Geology 46, 647-653.

Verosub, K.L., Fine, P., Singer, M.J., TenPas, J., 1993. Pedogenesis and paleoclimate: interpretation of the magnetic susceptibility record of Chinese loess-paleosol sequences. Geology 21, 1011-1014.

Wang, H., Follmer, L.R., Liu, J.C., 2000. Isotope evidence of paleo-El Niño-Southern Oscillation cycles in loess-paleosol record in the central United States. Geology 28, 771-774.

Wells, P.V., Stewart, J.D., 1987. Spruce charcoal, conifer macrofossils, and land snail and small-vertebrate faunas in Wisconsinan sediments on the High Plains of Kansas. In: Johnson, W.C. (Ed.), Quaternary Environments of Kansas. Kansas Geological Survey Guidebook Series, vol. 5, Kansas Geological Surveys, Lawrence, Kansas, pp. $129-140$.

Williams, J.R., 1986. New radiocarbon dates from the Matanuska Glacier bog section. U.S. Geological Survey Circular C-0978, 85-88. 